Sains Malaysiana 50(3)(2021): 791-801

http://dx.doi.org/10.17576/jsm-2021-5003-20

\title{
Honey Ameliorate Negative Effects in Neurodegenerative Diseases: An Evidence- Based Review
}

(Madu Memperbaiki Kesan Negatif dalam Penyakit Neurodegeneratif: Suatu Ulasan Berdasarkan Bukti)

ABID NORDIN, AMINUdDIN BIN SAIM \& RUSZYMAH BT HJ IDRUS*

\section{ABSTRACT}

Neurodegenerative diseases are cluster of disorders arising from neuronal cell death in the central nervous system. Its prevalence increases with increasing age. Therapeutic options for neurodegenerative disease include protection against oxidative damage, attenuation of neuroinflammation, maintenance of essential neurotransmitters, and protection against environmental factors that induce neurotoxicity. Honey with its antioxidative, anti-inflammatory, and cytoprotective effects is a potential candidate for therapy in neurodegenerative diseases. The present evidence-based review summarizes the effects of honey on neurodegenerative diseases in non-human subjects. Three electronic databases, namely PubMed, Ovid Medline and Scopus were searched for records published from inception of database to May 2020 to identify reports on the association of honey and neurodegenerative diseases. Based on the preset eligibility criteria, 8 qualified articles were selected and discussed in this review. Honey from different geological origin around the globe was used by different researcher among the studies included. Honey confers protection against oxidative stress induced by hypoxia and metabolic syndrome, aluminium toxicity, and neuroinflammation. Honey also demonstrated potential ability to inhibit neurotransmitters degrading enzymes and restore memory impairment. This review showed a sparse body of evidence on the potential of honey as neurodegenerative disease therapy.

Keywords: Antioxidant; honey; memory loss; neurodegenerative disease; regeneration

\section{ABSTRAK}

Penyakit neurodegeneratif adalah satu kumpulan penyakit yang muncul daripada kematian sel saraf di dalam sistem saraf pusat. Prevalens penyakit neurodegeneratif meningkat dengan peningkatan usia. Antara strategi rawatan penyakit ini adalah perlindungan daripada kerosakan oksidatif, pengawalan keradangan saraf, pemeliharaan neuropemancar penting dan perlindungan daripada faktor persekitaran yang boleh mengakibatkan ketoksikan saraf. Madu dengan kesan antioksida, anti-keradangan dan perlindungan sito merupakan calon yang berpotensi untuk perawatan penyakit neurodegeneratif dalam subjek bukan manusia. Tiga pengkalan data, PubMed, Ovid Medline dan Scopus digunakan untuk mengenal pasti rekod yang diterbitkan daripada permulaan pangkalan data sehingga Mei 2020 yang melaporkan kaitan madu dan penyakit neurodegeneratif. Berdasarkan kriteria yang ditetapkan, 8 artikel yang bersesuaian dipilih dan dibincangkan dalam kajian ini. Madu daripada punca geografi yang pelbagai di serata dunia telah digunakan oleh pengkaji yang berbeza disertakan dalam kajian ini. Madu menunjukkan perlindungan ke atas penyakit neurodegeneratif melalui perlindungan daripada tekanan oksida yang dihasilkan oleh kekurangan oksigen dan sindrom metabolik, perlindungan daripada ketoksikan aluminium dan perlindungan daripada keradangan saraf. Madu turut menunjukkan kebolehan untuk mencatutkan enzim penguraian neuropemancar dan memulihkan kehilangan memori. Kajian ini menunjukkan jurang pengetahuan dalam penggunaan madu untuk rawatan penyakit neurogeneratif.

Kata kunci: Antioksida; kehilangan memori; madu; penjanaan semula; penyakit neurodegeneratif

\section{INTRODUCTION}

\section{NEURODEGENERATIVE DISEASES}

Neurodegenerative disease is a cluster of disorders that arise as a consequence of neuronal death in the different parts of the brain, particularly the central nervous system
(CNS) (Berman \& Bayati 2018). Neurodegenerative diseases include Alzheimer's disease (AD), Parkinson's disease (PD), Huntington's disease (HD), or amyotrophic lateral sclerosis (ALS).

Since these different parts of the brain controls different functions, each disease has a unique clinical 
manifestation. For instance, Parkinson's disease, Huntington's disease and ALS are diseases that arise from neurodegeneration of the brain area that control movement, resulting in the inability to control movement. In Alzheimer's disease, a more disperse degeneration in the cerebral cortex resulted in loss of memory (Ahmad et al. 2017).

Neurodegenerative disorders manifested mainly in the elderly. The annual incidence of Alzheimer's disease (AD) has been shown to increase exponentially with advancing age (Haines 2018; Rubenstein et al. 2019). Similarly, incidence of Parkinson's disease (PD), the second most common age-related neurodegenerative condition also increases with age (Lee \& Gilbert 2016; Simon et al. 2020). Hence, ageing is considered as the most important risk factor for the development of neurodegenerative diseases (Kritsilis et al. 2018).

A long-standing hypothesis on the age-related pathophysiology is the slow and progressive accumulation of oxidative damage to macromolecules throughout the life span of an organisms (Schöttker et al. 2015; Speakman \& Selman 2011). Empirical evidences of oxidative stress as contributing factor in development of various disease has been well-established, including the neurodegenerative diseases (Chen et al. 2020; Nogueira et al. 2020; Shokr et al. 2020). Oxidative stress can induce cellular senescence within the neurons, the state where the neuron remains viable and metabolically active but may not perform its normal physiological function (Baker \& Petersen 2018; Martinez-Cue \& Rueda 2020). Hence, antioxidative agent may be potentially beneficial in the development of neurodegenerative therapy.

Amyloid plaque and neurofibrillary tangle, are two macromolecule abnormalities that define AD pathogenesis. Both phenomena were reported to exert a prion-like effect on the neuron following accumulation of misfolded amyloid beta $(A \beta)$ peptide in amyloid plaque and phosphorylation of tau protein in neurofibrillary tangle (Hu et al. 2020; Malek-Ahmadi et al. 2019; Sakakibara et al. 2019; Wu et al. 2020). Thus, targeting the inhibition of the amyloid plaque and neurofibrillary tangle in neuron are of paramount importance in $\mathrm{AD}$ therapy development.

Neurotransmitter is the chemical messenger which transmits signals across two adjacent neurons via a chemical synapse. The signal can either be excitatory or inhibitory and regulated by the mechanisms that either produce or degrade the neurotransmitter molecules. In AD pathology, reduced level of acetylcholine resulted in the impairment of memory formation (Moreira et al. 2017). The decreased level of acetylcholine is attributed to the increase activity of acetylcholinesterase (AChE), the enzyme responsible to degrade the excess acetylcholine after the completion of its signal transduction. Hence, inhibition of the AChE activity is an important target in the AD pathogenesis (Rosengarten et al. 2006; TorvinenKiiskinen et al. 2014). Similarly, inhibition of monoamine oxidase that degrades norepinephrine, has also been targeted in the AD pathogenesis (Schedin-Weiss et al. 2017; Yanez \& Vina 2013).

Furthermore, available evidences also suggest that many neurodegenerative diseases are not merely the diseases of dying neurons (Hemonnot et al. 2019; Marlatt et al. 2014; Mullard 2018; Sierksma et al. 2020; Taipa et al. 2018). Involvement of non-neuronal cells in the brain, which are even more abundant in the CNS than neurons, has been reported in the neurodegenerative pathogenesis. The presence of activated microglial cells, the immune cells of the brain, in neurodegenerative tissue, suggested the involvement of neuroinflammation in neurodegeneration. Elucidating these neuron-glial interactions will empower the understanding of the neurons non-autonomous disease mechanisms.

The role of environmental factors in neurodegenerative disease has gained significant interest among biomedical scientist in the last few decades (ChinChan et al. 2015; Groves-Kirkby et al. 2016; Maher 2019; Spencer et al. 2016). The late onset of these disease in the elderly is believed to be due to the prolong exposure to risk factors that occurred years or decades before its diagnosis. In cellular experimental models, neurotoxic metals such as lead, mercury, aluminium, cadmium and arsenic, as well as some pesticides and metal-based nanoparticles have been involved in $\mathrm{AD}$ due to their ability to increase $A \beta$ peptide and the phosphorylation of tau protein (Chin-Chan et al. 2015). Thus, an agent that can protect the neuron from the adverse effect of environmental factors exposure is relevant to the therapy of neurodegenerative diseases.

\section{HONEY PHYTOCHEMICALS}

Honey is a natural sweetener solution produced by the bee from either the nectar of plants, the secretions of living parts of plants, or the excretions of plant sucking insects on the living parts of plants. The aforementioned raw materials are collected and transformed into honey by combining them with specific substances of their own before being deposited, dehydrated, stored and left to be ripen and matured in the honey comb (CAC 2001).

It is made up of approximately $80 \%$ carbohydrate (35\% glucose, $40 \%$ fructose, and 5\% sucrose) and 20\% water. About 180 different substances inclusive of amino acids, vitamins and minerals have been reported to be contained in honey (Kumar et al. 2018). A consensus from a comprehensive review on honey composition showed that honey contains approximately $1.13 \%$ proteins, $0.36 \%$ minerals, $215.2 \mathrm{mg} / \mathrm{g}$ lipid, $15.5 \mathrm{mg} / \mathrm{kg}$ hydroxymethyl 
furfural, $13.2 \mathrm{mg} / \mathrm{g}$ vitamin C, 8.57 milliequivalents/ $\mathrm{kg}$ lactone and $873.3 \mathrm{mg} / \mathrm{kg}$ proline content. Among the major minerals that are known to be detected in honeys are sodium, potassium, calcium, magnesium, lead, sulfur, and chloride (Solayman et al. 2016).

\section{HONEY AND NEURODEGENERATIVE DISEASES}

The beneficial effect of honey on human health derives mainly from its content in phenolic compounds (Cianciosi et al. 2018). Among phenolic compounds reported in honey are chrysin, apigenin, pinobanksin, pinocembrin, and caffeic acid (Cheung et al. 2019). Honey in many forms, whether as crude solution, hydrophilic or hydrophobic extracts, has been reported to possess antioxidative (Chua et al. 2013), anti-inflammatory (Minden-Birkenmaier et al. 2019), and cytoprotective effects in a plethora of cells (Nordin et al. 2018). In this review, a systematic search of the literature was conducted to identify and discuss all available current evidence that report the association of honey and neurodegenerative diseases in non-human subjects. to guide the future utilization of honey as therapy in neurodegenerative diseases.

\section{METHODS}

\section{LITERATURE SEARCH}

Electronic database search was conducted to identify relevant studies reporting the therapeutic effects of honey or its constituent on neurodegenerative disease. Databases involved include PubMed, Ovid Medline, and Scopus. The search was not limited by time and include all records published from the inception of each database to May 2020. Keywords used were honey AND (neurodegenerative disease OR Alzheimer's disease OR Parkinson's disease OR Huntington's disease OR amyotrophic lateral sclerosis).

\section{ARTICLE SELECTION}

Literature findings were screened by two independent reviewers in a four stages process. First, any duplicate records found in the three databases were removed. Then, any articles that can be categorized as secondary literatures such as but not limited to review articles, editorials, news, letter, or book source were excluded. Next, primary literatures that were not related to honey or neurodegenerative disease based on title and abstract were excluded. Finally, full text articles were read through and selected according to the inclusion and exclusion criteria outlined.

\section{INCLUSION CRITERIA}

Original research articles (in vitro, in vivo or clinical study) that discuss the effect of honey or its bioactive compounds on neurodegeneration pathology published in English language.

\section{EXCLUSION CRITERIA}

Secondary literature (review articles, newsletter, or book chapter), not published in English language, studies that used synthetic compound not originally derived from honey, and studies that used bee propolis instead of its honey.

\section{DATA MANAGEMENT}

Data extraction was performed independently with the use of a data extraction form. The following data were recorded from the studies: The experimental model or study population used; type or form of honey or its constituent used; the outcome measures; a brief description of the results of the study; and the conclusion of the study.

\section{RESULTS}

\section{ELECTRONIC DATABASE FINDINGS}

The keyword search yielded a sum of 158 potential records across the three databases. Of this, 52 duplicate records from the three databases were removed. Then, 46 review articles and 1 conference proceedings were excluded from the screening process. From the title and abstracts, 51 articles were excluded from the screening process due to being not related to honey or any neurodegenerative disease parameter. Following our inclusion and exclusion criteria, all of the remaining 8 articles were eligible to be included in the review. All data were extracted directly from the articles. A flow chart of the selection process including reasons for exclusion is shown in Figure 1.

\section{STUDY CHARACTERISTICS}

The summary of the characteristics of all studies is displayed in Table 1. All studies included in the review were published between the year 2011 and 2020. In terms of honey used, each included study used different honey coming from diverse geographical origin, namely Algeria (Zaidi et al. 2019), Italy (Candiracci et al. 2012), Malaysia (Arshad et al. 2020; Saxena et al. 2014; Wan et al. 2020), Poland (Baranowska-Wojcik et al. 2020), Saudi Arabia (Shati et al. 2011) and Turkey (Yildiz et al. 2014). 


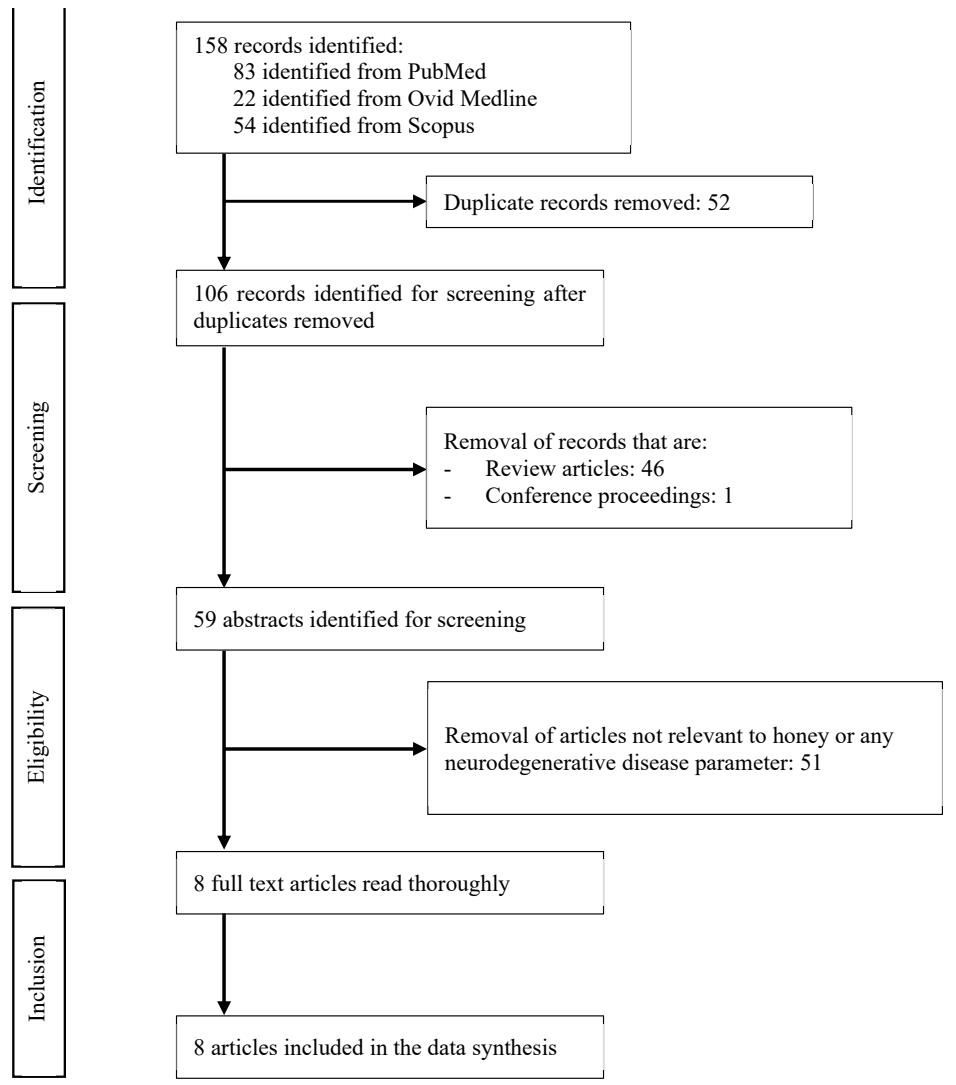

FIGURE 1. Flow chart of study selection procedure

TABLE 1. Studies summary of the effect of honey in cardiovascular diseases

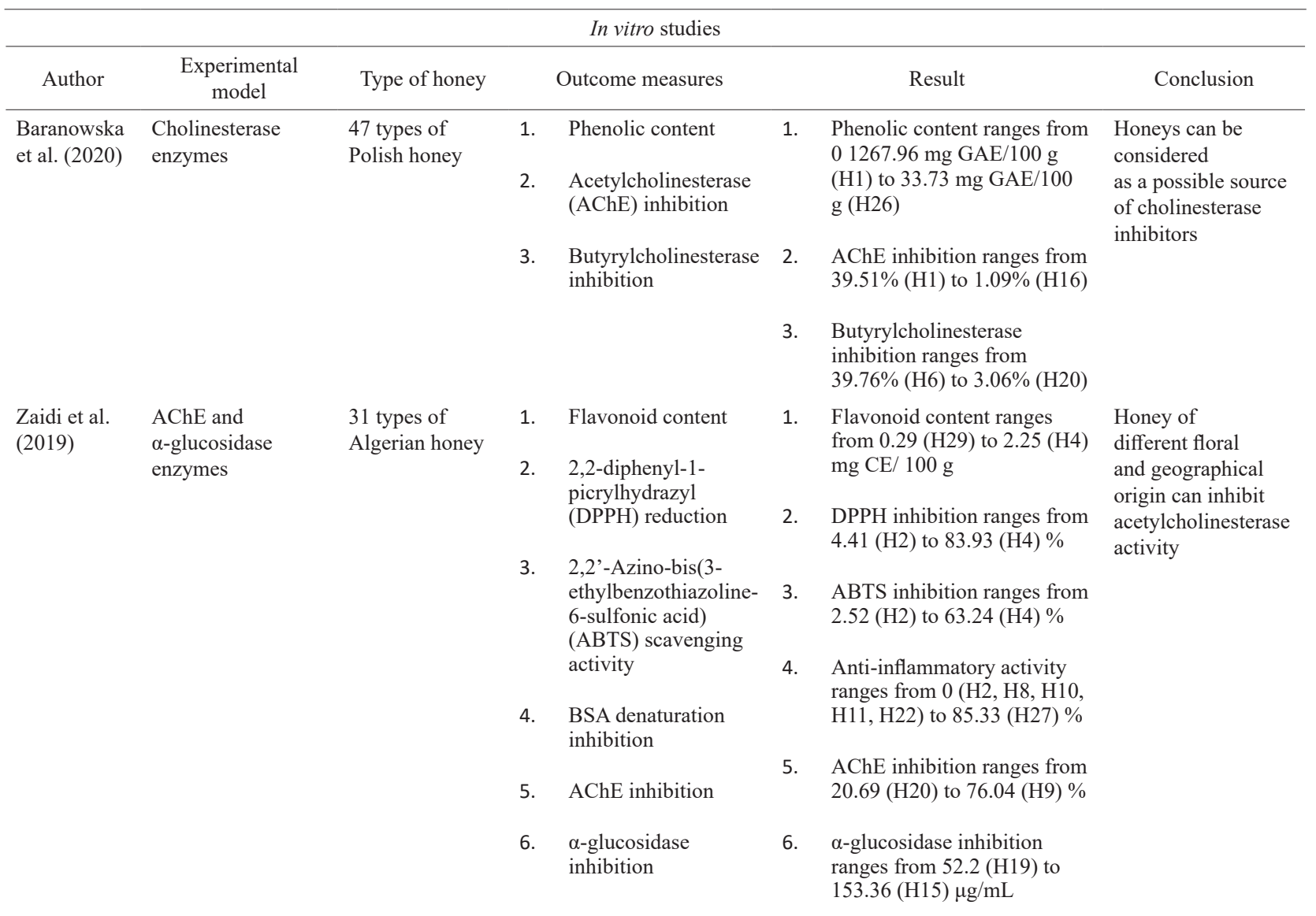




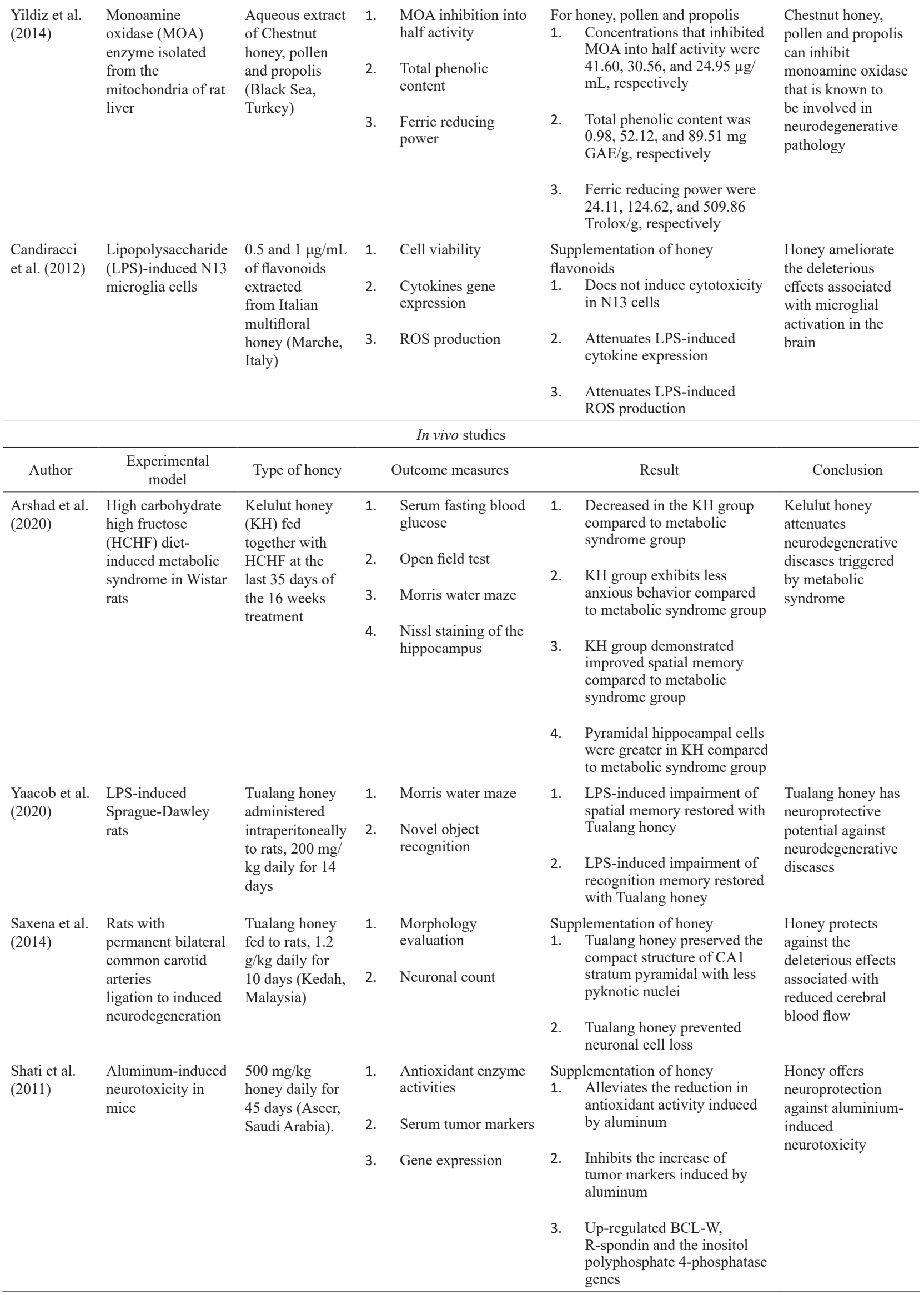


With regard to the type of studies, four in vitro studies and four in vivo studies were retrieved. The in vitro studies can be further categorized into cell-free biochemical assay, ex vivo enzymatic assay and cellular model. The two studies that included the cell-free assay tested their honey on cholinesterase, an important enzyme involved in the neurodegenerative pathology (Baranowska-Wojcik et al. 2020; Zaidi et al. 2019). The ex vivo enzymatic assay involved testing honey effect on the activity of monoamine oxidase isolated from the mitochondria of rat liver (Yildiz et al. 2014). The cellular model study utilizes lipopolysaccharide (LPS)-induced N19 microglial cells to model neuroinflammation in the brain (Candiracci et al. 2012).

There were four in vivo studies included, using mice and rats induced with plethora of factors. Neurodegeneration effect in rats was induced with cerebral hypoperfusion via ligation of the bilateral common carotid arteries (Saxena et al. 2014), LPS-induced inflammation (Wan et al. 2020), and high carbohydrate high fat (HCHF) diet-induced metabolic syndrome (Arshad et al. 2020). Meanwhile, the mice were injected with aluminium chloride to investigate protective effect of honey against aluminium-neurotoxicity (Shati et al. 2011).

\section{NEUROPROTECTIVE EFFECT OF HONEY AGAINST ENVIRONMENTAL FACTORS OF NEUROGENERATIVE DISEASE}

The increasing utility of aluminium as a vessel for food storage has been associated with neurodegenerative diseases such as Alzheimer's disease (Bondy 2016). Aluminium toxicity has been known to affect several enzymes and other molecules relevant to the disease pathology (Di Paolo et al. 2014). This prompt Shati et al. (2011) to produce the first report that linked the supplement of honey to neurodegenerative disease. They investigated the protective effect of feeding their aluminium -induced mice with honey obtained from Aseer, Saudi Arabia. Indeed, the honey supplementation exhibited protection from the impaired antioxidant capacity and elevation of tumor markers caused by the aluminium toxicity in mice brain (Shati et al. 2011).

\section{PROTECTIVE EFFECTS OF HONEY AGAINST CEREBRAL HYPOPERFUSION INDUCED NEURODEGENERATION}

The brain uses approximately $20 \%$ of available oxygen for normal function, making tight regulation of blood flow and oxygen delivery critical for survival. Reduced cerebral blood flow, has been associated with neurodegenerative disease such as Alzheimer and dementia due to elevation of the cellular oxidative stress (Zhao \& Gong 2015). Saxena et al. (2014) reported the protective effect of Tualang honey in rats with cerebral hypoperfusion-induced neurodegeneration. By introducing permanent bilateral common carotid arteries ligation in rat's brain, the hippocampal cells became damaged, distorted, irregular cells with shrunken cytoplasm and dark pykonotic nuclei. In the honey supplemented rats, the hippocampal cells remain normal despite undergoing the same procedure (Saxena et al. 2014).

\section{PROTECTIVE EFFECTS OF HONEY AGAINST NEUROINFLAMMATION INDUCED DEGENERATION}

Neuroinflammation has been considered as major contributor in the neurodegenerative disease pathology. Excessive release of the inflammatory molecules such as IL-1 $\beta$, TNF- $\alpha$, NO, and reactive oxygen intermediates (ROS) by the activated microglia cells, the immune cells of the brain, has been reported to be linked with neuronal death in the neurodegenerative process.

Leveraging their lipopolysaccharide (LPS)induced N13 microglia cells, Candiracci et al. (2012) reported the protective effect of honey flavonoids against neuroinflammation. Honey ameliorate the deleterious effects associated with microglial activation in the brain. The flavonoids were extracted from the Italian multifloral honey (Candiracci et al. 2012).

\section{INHIBITORY EFFECTS OF HONEY ON THE ENZYMES RELEVANT TO NEURODEGENERATIVE DISEASE}

Inhibition of the monoamine oxidase (MAO) is an important pharmacological process in the treatment of Alzheimer and Parkinson's diseases. Yildiz et al. (2014) investigated the MAO inhibition effect of the Chestnut honey, pollen and propolis from the Black Sea region in Turkey. All three of the bee product inhibited MAO activity. Propolis exhibited the strongest inhibition followed by pollen and finally honey. Antioxidant capacity and phenolic content of the bee products have the similar pattern with propolis being the strongest and honey being the weakest antioxidants. Based on the results, they hypothesized that the MAO inhibition might have a direct relationship with the phenolic content with each individual bee product (Yildiz et al. 2014).

Another important enzyme in the neurodegenerative disease pathology is the cholinesterase. In Alzheimer's disease, low level of acetylcholine, the neurotransmitter 
essential for processing memory and learning, is a welldocumented occurrence contributing to its pathology. The reduced level of the neurotransmitter is the result of the overactivity of acetylcholinesterase (AChE), the enzyme responsible to degrade excess acetylcholine in the neurons. As such, one of the targets of AD treatment is to increase the level of acetylcholine in the brain by inhibiting the AChE.

Zaidi et al. (2019) investigated the effect of 31 Algerian Honey on the inhibition of AChE. For the polyfloral honeys, the inhibition of AChE ranged from 20.69 (H20) to $76.04 \%$ (H9) and from 39.89 (H6) to $67.15 \%$ (H19) for monofloral honeys. Sample H9 had the best AChE inhibition and the results obtained was significantly different from the others. They concluded that all of their honey samples were able to inhibits AChE and the effects varied according to the geographical and floral origin of the honey.

Similarly, Baranoswka et al. (2020) investigated the effect of 47 Polish honey on the inhibition of AChE as well as the less specific choline ester enzymes, butyrylcholinesterase. They also found a variation of effects according to the floral origin of their honey. In this study, the highest AChE inhibition (39.51\%) was observed in buckwheat honey and the lowest (1.09\%) was found in multi-floral honey. The highest AChE inhibition by buckwheat honey might be attributed to its phenolic content which also reported to be the highest among all honey. Some honeys showed no AChE inhibition at all. For butyrylcholinesterase, the highest significant inhibition
(39.76\%) was observed in multi-floral honey and the lowest result (3.06\%) was obtained for honeydew honey. One honey did not show any inhibition for this enzyme (Baranowska-Wojcik et al. 2020).

\section{EFFECTS OF HONEY ON MEMORY IMPAIRMENT}

Animal models of memory impairment have been established to investigate potential therapeutics for neurodegenerative disease. From the literature search, two studies elucidated the effect of honey in memory impairment. Malaysian honeys, namely Tualang and Kelulut demonstrated improvement on the experimentally induced memory impairment. In the study by Wan et al. (2020), memory impairment was induced by LPS in Sprague-Dawley rats. Tualang honey demonstrated an improvement in spatial and recognition memory following LPS-induced memory impairment (Wan et al. 2020). In another study, Arshad et al. (2020) induced memory impairment with HCHF diet-induced metabolic syndrome in Wistar rats. Kelulut honey demonstrated an improvement of spatial memory as indicated by the better performance in the Morris water maze test. Kelulut honey also exhibits anxiety reducing effect in the metabolic syndrome rat model (Arshad et al. 2020).

\section{DISCUSSION}

The present systematic review showed a limited body of literature on the potential benefits of honey in neurodegenerative diseases. Figure 2 illustrates the benefits of honey in neurodegenerative diseases.

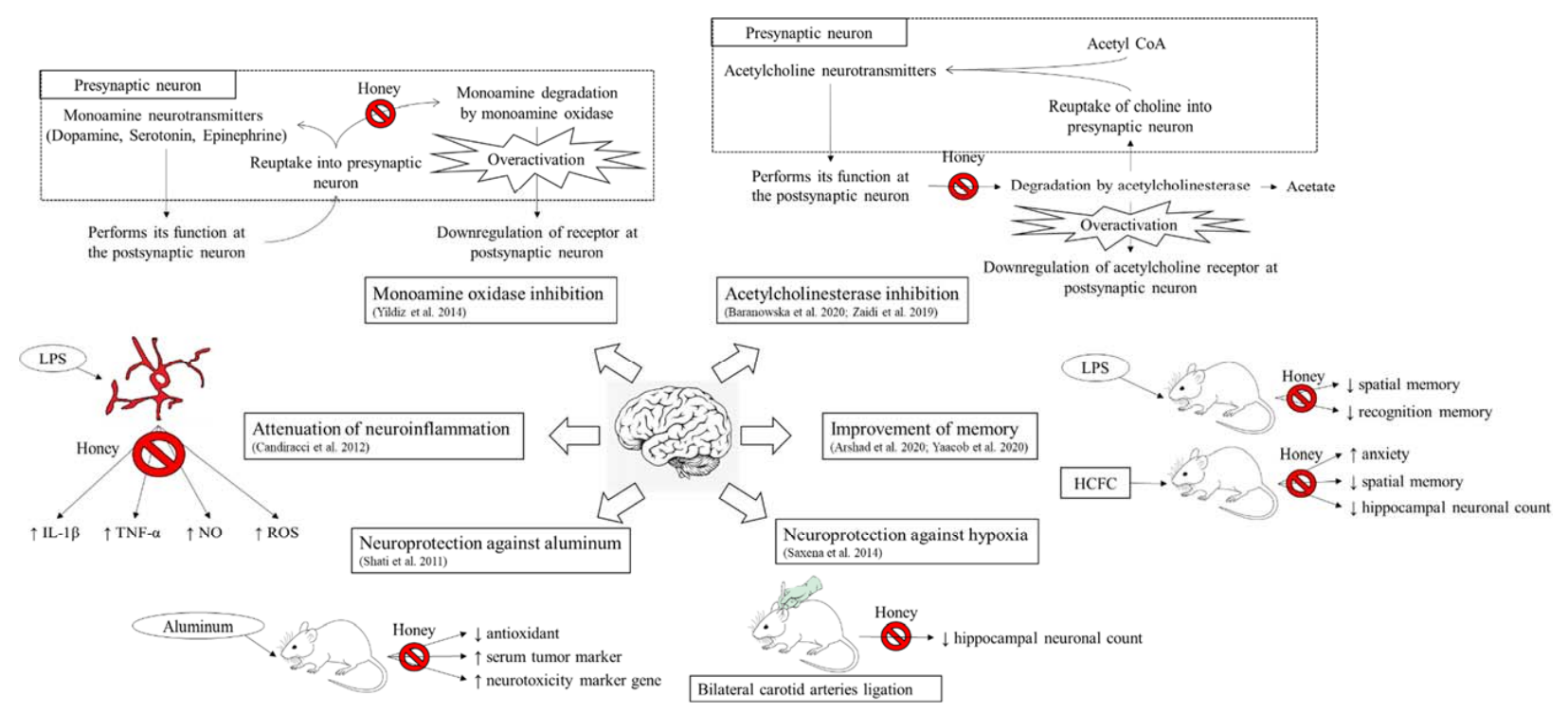

FIGURE 2. Benefits of honey in neurodegenerative diseases 
Although the protocol outlined intended to identify evidence of honey benefits in wider category of neurodegenerative diseases, only studies pertaining to Alzheimer's and Parkinson's diseases were identified. This could be due to the more widespread prevalence of these two diseases compared to other forms of neurodegenerative diseases such as Huntington's disease and amyotrophic lateral sclerosis.

From the identified articles to be included in the data synthesis of the review, six studies that utilized known molecules found in honey in their neurodegenerative disease experimental model were excluded (Barros Silva et al. 2013; Ferreira et al. 2018; Fontanilla et al. 2011; Goes et al. 2018; Ha et al. 2010; Jin et al. 2015; Kurauchi et al. 2012; Lee et al. 2017; Liu et al. 2012; Noelker et al. 2005; Wang et al. 2014, 2016; Zaitone et al. 2019). The exclusion of these studies was in accordance with the exclusion criteria that exclude any study that used synthetic compound not originally derived from honey. Although frequently reported in honey, certain flavonoids such as pinobanksin, pinocembrin, or caffeic acid can also be isolated from a variety of plants such as ginger, coneflower, or St John's wort. Thus, the use of synthetic compound not originally derived from honey might not represent the effect of honey in neurodegenerative diseases.

Moreover, six studies that were done on propolis were also excluded from the final review (Chen et al. 2008; Hussein et al. 2017; Nanaware et al. 2017; Ni et al. 2017; Swamy et al. 2014; Zhu et al. 2018). Propolis is the building block of the honey hive that is fortified with resin. This might alter the properties of the propolis and resulted in a distinct biological effect compared to the honey. Thus, the two components might not be comparable to each other. However, considering report of the effect of honey in monoamine oxidase activity, study by Yildiz et al. (2014) was still included in the review.

Recent strategies toward the discovery of novel therapeutics for neurodegenerative disease can be categorized into four, namely protection against oxidative damage, attenuation of neuroinflammation, inhibition of neurotransmitters degrading enzymes, and protection against environmental factors that induce neurotoxicity. Despite the small amount of evidences retrieved, all strategies were covered in the studies included in the data synthesis. As a result, the evidences were comprehensive in terms of putting the honey into the context of neurodegenerative therapy but not enough to allow judgement on its clinical benefit. Moreover, the lack of any human studies supports the cautionary concern in interpreting honey effect on neurodegenerative diseases.

\section{CONCLUSION}

The review showed a sparse in vitro and in vivo evidences on the effect of honey in neurodegenerative diseases. Honey confers protection against oxidative stress induced by hypoxia and metabolic syndrome, aluminium toxicity, and neuroinflammation. Honey also demonstrated potential ability to inhibit neurotransmitters degrading enzymes and restore memory impairment.

\section{ACKNOWLEDGEMENTS}

This research was made possible via provision of funding by Amrus Medik Sdn. Bhd. We would also like to acknowledge Universiti Kebangsaan Malaysia for the resources required in completion of the review.

\section{REFERENCES}

Ahmad, K., Baig, M.H., Mushtaq, G., Kamal, M.A., Greig, N.H. \& Choi, I. 2017. Commonalities in biological pathways, genetics, and cellular mechanism between alzheimer disease and other neurodegenerative diseases: An in silicoupdated overview. Current Alzheimer Research 14(11): 1190-1197.

Arshad, N.A., Lin, T.S. \& Yahaya, M.F. 2020. Stingless bee honey reduces anxiety and improves memory of the metabolic disease-induced rats. CNS \& Neurological Disorders Drug Targets 19(2): 115-126.

Baker, D.J. \& Petersen, R.C. 2018. Cellular senescence in brain aging and neurodegenerative diseases: evidence and perspectives. Journal of Clinical Investigation 128(4): 1208-1216.

Baranowska-Wojcik, E., Szwajgier, D. \& Winiarska-Mieczan, A. 2020. Honey as the potential natural source of cholinesterase inhibitors in Alzheimer's disease. Plant Foods for Human Nutrition 75(1): 30-32.

Berman, T. \& Bayati, A. 2018. What are neurodegenerative diseases and how do they affect the brain? Frontiers for Young Minds 6(70). doi: 10.3389/frym.2018.00070.

Bondy, S.C. 2016. Low levels of aluminum can lead to behavioral and morphological changes associated with Alzheimer's disease and age-related neurodegeneration. Neurotoxicology 52: 222-229.

CAC. 2001. Alinorm 41/10: Revised Standard for Honey. Rome: Codex Alimentarius Commission (CAC).

Candiracci, M., Piatti, E., Dominguez-Barragan, M., GarciaAntras, D., Morgado, B., Ruano, D., Gutiérrez, J.F., Parrado, J. \& Castaño, A. 2012. Anti-inflammatory activity of a honey flavonoid extract on lipopolysaccharide-activated N13 microglial cells. Journal of Agricultural and Food Chemistry 60(50): 12304-12311.

Chen, J., Long, Y., Han, M., Wang, T., Chen, Q. \& Wang, R. 2008. Water-soluble derivative of propolis mitigates scopolamine-induced learning and memory impairment in mice. Pharmacology Biochemistry and Behavior 90(3): 441-446. 
Chen, Z., Tian, R., She, Z., Cai, J. \& Li, H. 2020. Role of oxidative stress in the pathogenesis of nonalcoholic fatty liver disease. Free Radical Biology and Medicine 52(1): 116-141.

Cheung, Y., Meenu, M., Yu, X. \& Xu, B. 2019. Phenolic acids and flavonoids profiles of commercial honey from different floral sources and geographic sources. International Journal of Food Properties 22(1): 290-308.

Chin-Chan, M., Navarro-Yepes, J. \& Quintanilla-Vega, B. 2015. Environmental pollutants as risk factors for neurodegenerative disorders: Alzheimer and Parkinson diseases. Frontiers in Cellular Neuroscience 9: 124

Chua, L.S., Rahaman, N.L.A., Adnan, N.A. \& Eddie Tan, T.T. 2013. Antioxidant activity of three honey samples in relation with their biochemical components. Journal of Analytical Methods in Chemistry 2013: 313798.

Cianciosi, D., Forbes-Hernandez, T.Y., Afrin, S., Gasparrini, M., Reboredo-Rodriguez, P., Manna, P.P., Zhang, J., Bravo Lamas, L., Martínez Flórez, S., Agudo Toyos, P. \& Quiles, J.L. 2018. Phenolic compounds in honey and their associated health benefits: A review. Molecules 23(9): 2322.

Di Paolo, C., Reverte, I., Colomina, M.T., Domingo, J.L. \& Gomez, M. 2014. Chronic exposure to aluminum and melatonin through the diet: Neurobehavioral effects in a transgenic mouse model of Alzheimer disease. Food and Chemical Toxicology 69: 320-329.

Ferreira, R.S., Dos Santos, N.A.G., Martins, N.M., Fernandes, L.S. \& Dos Santos, A.C. 2018. Caffeic acid phenethyl ester (CAPE) protects PC12 cells from cisplatin-induced neurotoxicity by activating the NGF-signaling pathway. Neurotoxicity Research 34(1): 32-46.

Fontanilla, C.V., Ma, Z., Wei, X., Klotsche, J., Zhao, L., Wisniowski, P., Dodel, R.C., Farlow, M.R., Oertel, W.H. \& Du, Y. 2011. Caffeic acid phenethyl ester prevents 1-methyl-4-phenyl-1,2,3,6-tetrahydropyridine-induced neurodegeneration. Neuroscience 188: 135-141.

Goes, A.T.R., Jesse, C.R., Antunes, M.S., Ladd, F.V.L., Ladd, A.A.B.L., Luchese, C., Paroul N., \& Boeira, S.P. 2018. Protective role of chrysin on 6-hydroxydopamine-induced neurodegeneration a mouse model of Parkinson's disease: Involvement of neuroinflammation and neurotrophins. Chemico-Biological Interactions 279: 111-120.

Groves-Kirkby, C.J., Denman, A.R., Campbell, J., Crockett, R.G., Phillips, P.S. \& Rogers, S. 2016. Is environmental radon gas associated with the incidence of neurodegenerative conditions? A retrospective study of multiple sclerosis in radon affected areas in England and Wales. Journal of Environmental Radioactivity 154: 1-14.

Ha, S.K., Moon, E. \& Kim, S.Y. 2010. Chrysin suppresses LPSstimulated proinflammatory responses by blocking NF-kB and JNK activations in microglia cells. Neuroscience Letter 485(3): 143-147.

Haines, J.L. 2018. Alzheimer disease: Perspectives from epidemiology and genetics. The Journal of Law, Medicine \& Ethics 46(3): 694-698.

Hemonnot, A.L., Hua, J., Ulmann, L. \& Hirbec, H.E. 2019. Microglia in Alzheimer disease: Well-known targets and new opportunities. Frontiers in Aging Neuroscience 11: 233.
Hu, S., Hu, M., Liu, J., Zhang, B., Zhang, Z., Zhou, F.H., Wang, L. \& Dong, J. 2020. Phosphorylation of Tau and alphaSynuclein induced neurodegeneration in MPTP mouse model of Parkinson's disease. Neuropsychiatric Disease and Treatment 16: 651-663.

Hussein, U.K., Hassan, N.E.H.Y., Elhalwagy, M.E., Zaki, A.R., Abubakr, H.O., Nagulapalli Venkata, K.C., Jang, K.Y. \& Bishayee, A. 2017. Ginger and propolis exert neuroprotective effects against monosodium glutamate-induced neurotoxicity in rats. Molecules 22(11): 1928.

Jin, X., Liu, Q., Jia, L., Li, M. \& Wang, X. 2015. Pinocembrin attenuates 6-OHDA-induced neuronal cell death through Nrf2/ARE pathway in SH-SY5Y cells. Cellular and Molecular Neurobiology 35(3): 323-333.

Kritsilis, M., Rizou, S.V., Koutsoudaki, P.N., Evangelou, K., Gorgoulis, V.G. \& Papadopoulos, D. 2018. Ageing, cellular senescence and neurodegenerative disease. International Journal of Molecular Sciences 19(10): 2937.

Kumar, A., Gill, J.P.S., Bedi, J.S., Manav, M., Ansari, J. \& Walia, G.S. 2018. Sensorial and physicochemical analysis of Indian honeys for assessment of quality and floral origins. Food Research International 108: 571-583.

Kurauchi, Y., Hisatsune, A., Isohama, Y., Mishima, S. \& Katsuki, H. 2012. Caffeic acid phenethyl ester protects nigral dopaminergic neurons via dual mechanisms involving haem oxygenase-1 and brain-derived neurotrophic factor. British Journal of Pharmacology 166(3): 1151-1168.

Lee, A. \& Gilbert, R.M. 2016. Epidemiology of Parkinson disease. Neurologic Clinics 34(4): 955-965.

Lee, B.K., Lee, W.J. \& Jung, Y.S. 2017. Chrysin attenuates VCAM1 expression and monocyte adhesion in lipopolysaccharidestimulated brain endothelial cells by preventing NF- $\mathrm{kB}$ signaling. International Journal of Molecular Sciences 18(7): 1424.

Liu, R., Wu, C.X., Zhou, D., Yang, F., Tian, S., Zhang, L., Zhang, T.T. \& Du, G.H. 2012. Pinocembrin protects against $\beta$-amyloid-induced toxicity in neurons through inhibiting receptor for advanced glycation end products (RAGE)-independent signaling pathways and regulating mitochondrion-mediated apoptosis. BMC Medicine 10(1): 105.

Maher, B.A. 2019. Airborne magnetite- and iron-rich pollution nanoparticles: Potential neurotoxicants and environmental risk factors for neurodegenerative disease, including Alzheimer's disease. Journal of Alzheimer's Disease 71(2): 361-375.

Malek-Ahmadi, M., Chen, K., Perez, S.E. \& Mufson, E.J. 2019. Cerebral amyloid angiopathy and neuritic plaque pathology correlate with cognitive decline in elderly non-demented individuals. Journal of Alzheimer's Disease 67(1): 411-422.

Marlatt, M.W., Bauer, J., Aronica, E., van Haastert, E.S., Hoozemans, J.J., Joels, M. \& Lucassen, P.J. 2014. Proliferation in the Alzheimer hippocampus is due to microglia, not astroglia, and occurs at sites of amyloid deposition. Neural Plasticity 2014: 693851.

Martinez-Cue, C. \& Rueda, N. 2020. Cellular senescence in neurodegenerative diseases. Frontiers in Cellular Neuroscience 14: 16. 
Minden-Birkenmaier, B.A., Cherukuri, K., Smith, R.A., Radic, M.Z. \& Bowlin, G.L. 2019. Manuka honey modulates the inflammatory behavior of a dHL-60 neutrophil model under the cytotoxic limit. International Journal of Biomaterials 2019: 6132581.

Moreira, F.T.C., Sale, M.G.F. \& Di Lorenzo, M. 2017. Towards timely Alzheimer diagnosis: A self-powered amperometric biosensor for the neurotransmitter acetylcholine. Biosensors and Bioelectronics 87: 607-614.

Mullard, A. 2018. Microglia-targeted candidates push the Alzheimer drug envelope. Nature Reviews Drug Discovery 17: 303-305.

Nanaware, S., Shelar, M., Sinnathambi, A., Mahadik, K.R. \& Lohidasan, S. 2017. Neuroprotective effect of Indian propolis in beta-amyloid induced memory deficit: Impact on behavioral and biochemical parameters in rats. Biomedicine \& Pharmacotherapy 93: 543-553.

Ni, J., Wu, Z., Meng, J., Zhu, A., Zhong, X., Wu, S. \& Nakanishi, H. 2017. The neuroprotective effects of Brazilian green propolis on neurodegenerative damage in human neuronal SH-SY5Y cells. Oxidative Medicine and Cellular Longevity 2017: 7984327.

Noelker, C., Bacher, M., Gocke, P., Wei, X., Klockgether, T., Du, Y. \& Dodel, R. 2005. The flavanoide caffeic acid phenethyl ester blocks 6-hydroxydopamine-induced neurotoxicity. Neuroscience Letter 383(1-2): 39-43.

Nogueira, F.N., Romero, A.C., Pedrosa, M.D.S., Ibuki, F.K. \& Bergamaschi, C.T. 2020. Oxidative stress and the antioxidant system in salivary glands of rats with experimental chronic kidney disease. Archives of Oral Biology 113: 104709.

Nordin, A., Omar, N., Sainik, N.Q.A.V., Chowdhury, S.R., Omar, E., Bin Saim, A. \& Idrus, R.B.H. 2018. Low dose stingless bee honey increases viability of human dermal fibroblasts that could potentially promote wound healing. Wound Medicine 23: 22-27.

Rosengarten, B., Paulsen, S., Molnar, S., Kaschel, R., Gallhofer, B. \& Kaps, M. 2006. Acetylcholine esterase inhibitor donepezil improves dynamic cerebrovascular regulation in Alzheimer patients. Journal of Neurology 253(1): 58-64.

Rubenstein, E., Hartley, S. \& Bishop, L. 2019. Epidemiology of dementia and Alzheimer disease in individuals with down syndrome. JAMA Neurology 77(2): 262-264.

Sakakibara, Y., Sekiya, M., Saito, T., Saido, T.C. \& Iijima, K.M. 2019. Amyloid-beta plaque formation and reactive gliosis are required for induction of cognitive deficits in App knock-in mouse models of Alzheimer's disease. BMC Neuroscience 20(1): 13.

Saxena, A.K., Phyu, H.P., Al-Ani, I.M. \& Talib, N.A. 2014. Potential protective effect of honey against chronic cerebral hypoperfusion-induced neurodegeneration in rats. Journal of the Anatomical Society of India 63(2): 151-155.

Schedin-Weiss, S., Inoue, M., Hromadkova, L., Teranishi, Y., Yamamoto, N.G., Wiehager, B., Bogdanovic, N., Winblad, B., Sandebring-Matton, A., Frykman, S. \& O. Tjernberg, L. 2017. Monoamine oxidase $b$ is elevated in Alzheimer disease neurons, is associated with gamma-secretase and regulates neuronal amyloid beta-peptide levels. Alzheimer's Research \& Therapy 9(1): 1-19.

Schöttker, B., Brenner, H., Jansen, E.H., Gardiner, J., Peasey, A., Kubínová, R., Pająk, A., Topor-Madry, R., Tamosiunas, A., Saum, K.U. \& Holleczek, B. 2015. Evidence for the free radical/oxidative stress theory of ageing from the CHANCES consortium: A meta-analysis of individual participant data. BMC Medicine 13(1): 300.

Shati, A.A., Elsaid, F.G. \& Hafez, E.E. 2011. Biochemical and molecular aspects of aluminium chloride-induced neurotoxicity in mice and the protective role of Crocus sativus L. extraction and honey syrup. Neuroscience 175: 66-74.

Shokr, H., Dias, I.H.K. \& Gherghel, D. 2020. Microvascular function and oxidative stress in adult individuals with early onset of cardiovascular disease. Scientific Reports 10(1): 1-8.

Sierksma, A., Lu, A., Mancuso, R., Fattorelli, N., Thrupp, N., Salta, E., Zoco, J., Blum, D., Buée, L., De Strooper, B. \& Fiers, M. 2020. Novel Alzheimer risk genes determine the microglia response to amyloid-beta but not to TAU pathology. EMBO Molecular Medicine 12(3): e10606.

Silva, R.B., Santos, N.A.G., Martins, N.M., Ferreira, D.A.S., Barbosa Jr., F., Oliveira Souza, V.C., Kinoshita, A., Baffa, O., Del-Bel, E. \& Santos, A.C. 2013. Caffeic acid phenethyl ester protects against the dopaminergic neuronal loss induced by 6-hydroxydopamine in rats. Neuroscience 233: 86-94.

Simon, D.K., Tanner, C.M. \& Brundin, P. 2020. Parkinson disease epidemiology, pathology, genetics, and pathophysiology. Clinics in Geriatric Medicine 36(1): 1-12.

Solayman, M., Islam, M.A., Paul, S., Ali, Y., Khalil, M.I., Alam, N. \& Gan, S.H. 2016. Physicochemical properties, minerals, trace elements, and heavy metals in honey of different origins: A comprehensive review. Comprehensive Reviews in Food Science and Food Safety 15(1): 219-233.

Speakman, J.R. \& Selman, C. 2011. The free-radical damage theory: Accumulating evidence against a simple link of oxidative stress to ageing and lifespan. Bioessays 33(4): 255-259.

Spencer, P.S., Palmer, V.S. \& Kisby, G.E. 2016. Seeking environmental causes of neurodegenerative disease and envisioning primary prevention. Neurotoxicology 56: 269283.

Swamy, M., Suhaili, D., Sirajudeen, K.N., Mustapha, Z. \& Govindasamy, C. 2014. Propolis ameliorates tumor nerosis factor-alpha, nitric oxide levels, caspase- 3 and nitric oxide synthase activities in kainic acid mediated excitotoxicity in rat brain. African Journal of Traditional, Complementary and Alternative Medicines 11(5): 48-53.

Taipa, R., Ferreira, V., Brochado, P., Robinson, A., Reis, I., Marques, F., Mann, D.M., Melo-Pires, M. \& Sousa, N. 2018. Inflammatory pathology markers (activated microglia and reactive astrocytes) in early and late onset Alzheimer disease: A post mortem study. Neuropathology and Applied Neurobiology 44(3): 298-313.

Torvinen-Kiiskinen, S., Taipale, H., Tanskanen, A., Tiihonen, J. \& Hartikainen, S. 2014. Concomitant use of acetylcholine esterase inhibitors and urinary antispasmodics among Finnish 
community-dwelling persons with Alzheimer disease. Journal of Clinical Psychopharmacology 34(6): 722-727.

Wan, M.H.W.Y., Idris, L., Rahimah, Z. \& Zahiruddin, O. 2020. Tualang honey and its methanolic fraction improve lpsinduced learning and memory impairment in male rats: Comparison with memantine. Current Nutrition \& Food Science 16(3): 333-342.

Wang, H., Wang, Y., Zhao, L., Cui, Q., Wang, Y. \& Du, G. 2016. Pinocembrin attenuates MPP(+)-induced neurotoxicity by the induction of heme oxygenase-1 through ERK1/2 pathway. Neuroscience Letter 612: 104-109.

Wang, Y., Gao, J., Miao, Y., Cui, Q., Zhao, W., Zhang, J. \& Wang, H. 2014. Pinocembrin protects SH-SY5Y cells against $\mathrm{MPP}+$-induced neurotoxicity through the mitochondrial apoptotic pathway. Journal of Molecular Neuroscience 53(4): 537-545.

Wu, H., Wei, S., Huang, Y., Chen, L., Wang, Y., Wu, X., Zhang, Z., Pei, Y. \& Wang, D. 2020. A $\beta$ monomer induces phosphorylation of Tau at Ser-214 through beta2ARPKA-JNK signaling pathway FASEB Journal 34(4): 50925105.

Yanez, M. \& Vina, D. 2013. Dual inhibitors of monoamine oxidase and cholinesterase for the treatment of Alzheimer disease. Current Topics in Medicinal Chemistry 13(14): 1692-1706.

Yildiz, O., Karahalil, F., Can, Z., Sahin, H. \& Kolayli, S. 2014. Total monoamine oxidase (MAO) inhibition by chestnut honey, pollen and propolis. Journal of Enzyme Inhibition and Medicinal Chemistry 29(5): 690-694.

Zaidi, H., Ouchemoukh, S., Amessis-Ouchemoukh, N., Debbache, N., Pacheco, R., Serralheiro, M.L. \& Araujo, M.E. 2019. Biological properties of phenolic compound extracts in selected Algerian honeys - The inhibition of acetylcholinesterase and $\alpha$-glucosidase activities. European Journal of Integrative Medicine 25: 77-84.

Zaitone, S.A., Ahmed, E., Elsherbiny, N.M., Mehanna, E.T., El-Kherbetawy, M.K., ElSayed, M.H., Alshareef, D.M. \& Moustafa, Y.M. 2019. Caffeic acid improves locomotor activity and lessens inflammatory burden in a mouse model of rotenone-induced nigral neurodegeneration: Relevance to Parkinson's disease therapy. Pharmacological Reports 71(1): 32-41.

Zhao, Y. \& Gong, C.X. 2015. From chronic cerebral hypoperfusion to Alzheimer-like brain pathology and neurodegeneration. Cellular and Molecular Neurobiology 35(1): 101-110.

Zhu, A., Wu, Z., Zhong, X., Ni, J., Li, Y., Meng, J., Du, C., Zhao, X., Nakanishi, H. \& Wu, S. 2018. Brazilian green propolis prevents cognitive decline into mild cognitive impairment in elderly people living at high altitude. Journal of Alzheimer's Disease 63(2): 551-560.

Abid Nordin \& Ruszymah Bt Hj Idrus*

Department of Physiology

Universiti Kebangsaan Malaysia

Jalan Yaacob Latif, Bandar Tun Razak

56000 Cheras, Kuala Lumpur, Federal Territory

Malaysia

Abid Nordin \& Ruszymah Bt Hj Idrus*

Centre for Tissue Engineering and Regenerative Medicine, Clinical Block

UKM Medical Centre, Jalan Yaacob Latif

56000 Cheras, Kuala Lumpur, Federal Territory

Malaysia

Aminuddin Bin Saim

Ear, Nose and Throat Consultant Clinic

Ampang Puteri Specialist Hospital

Taman Dato Ahmad Razali

68000 Ampang, Selangor Darul Ehsan

Malaysia

*Corresponding author; email: ruszyidrus@gmail.com

Received: 12 July 2020

Accepted: 25 August 2020 